\title{
Mengembangkan Kemampuan Mengenal Bilangan dan Lambang Bilangan Pada Anak dengan Permainan Jual-Beli
}

\author{
Devi Wahyu Alfia Nita ${ }^{\text {a, }}$ Made Ayu Anggreni ${ }^{\text {b }}$ \\ ${ }^{\text {a }}$ Universitas PGRI Adibuana Surabaya \\ ${ }^{\mathrm{b}}$ Universitas PGRI Adibuana Surabaya \\ e-mail korespondensi: devidinata26@gmail.com
}

\begin{abstract}
This research is motivated by the school environment that develops the ability to recognize the numbers and the symbol of the number of children is still centered on the teacher, so the ability of the child is still not developed. Therefore, to develop the ability to recognize numbers and symbols of numbers need to be done in the right way, that is by using the role playing method of buying and selling. The purpose of this study to determine the ability to recognize the number and symbol of the number of children before and after the applied method of selling role play. This research uses pre-experimental design design with one-group pretestposttest design. The subjects of this study were 18 children. Data analysis applied in this research is different test technique of pre-test and post-test ( $t$ test) from activity observation of children to know the ability to recognize numbers and symbol of number through play role of buying and selling. The result of data analysis shows the value of 21,17 and 1,74 at $\alpha 0,05$ and 2,57 at $\alpha 0,01$, then $t_{\text {hitung }}>t_{\text {tabel }}$ rejected and accepted. Thus, it can be concluded that playing the role of buying and selling affects the ability to recognize numbers and symbols of numbers in of kindergartens children.
\end{abstract}

Keywords: Know number and symbol of numbers, play the role of buying and selling.

\section{PENDAHULUAN}

Pendidikan anak usia dini pada hakikatnya, pendidikan yang di selenggarakan dengan tujuan untuk memfasilitasi pertumbuhan dan perkembangan anak secara menyeluruh atau menekankan pada pengembangan seluruh aspekaspek perkembangan anak.

Montessori (dalam Sujiono, 2009:2) menyatakan masa peka adalah masa terjadinya kematangan fungsi fisik dan psikis, anak telah siap merespon stimulasi yang diberikan oleh lingkungan. Masa ini merupakan landasan awal untuk mengembangkan kemampuan anak di bidangnilai agama dan moral, kognitif, bahasa, fisik-motorik, sosial emosional, dan seni.
Pengembangan aspek tersebut bermuara pada peningkatan kecakapan hidup yang diwujudkan melalui pencapaian kompetensi peserta didik untuk bertahan hidup serta menyesuaikan diri dan berhasil dalam kehidupan melalui keenam aspek perkembangan ini dibangun dari pengalaman dan interaksi yang dilakukan anak melalui bermain. Dalam kegiatan mengenal konsep bilangan dan lambang bilangan, kemampuan anak masih kurang. Hanya ada beberapa atau 5 anak saja yang bisa memahami konsep bilangan dan lambang bilangan. Anak hanya mampu membilang dengan hafalan 110 dengan jumlah 7 anak, anak belum memahami konsep bilangan dan lambang bilangan. Terlihat 6 anak masih bingung ketika ditanya bilangan dan lambangnya secara acak, belum memahami konsep bilangan 1-10. 
Menurut Bergen (2002:3), permainan peran (pretend play) memiliki peran yang penting dalam meningkatkan kemampuan kognitif anak di awal perkembangannya. Pada pembelajaran berhitung, pengenalan pada aritmetika yang diterapkan Montessori (2013:363), beragam cara dapat digunakan untuk mengajarkan berhitung. Salah satu permainan yang bisa digunakan adalah menghitung dengan uang. Menggunakan uang tiruan anak-anak melakukan permainan bertukar uang dan menyajikan satu, dua, dan empat keping uang dan anak-anak akan berhitung sampai sepuluh.

Kemampuan dan minat anak pada tahapan perkembangan di usia 4-5 tahun mengalami banyak perubahan yang berarti, anak pada usia ini umumnya sudah memiliki kematangan pada seluruh kemampuannya. Salah satunya yaitu dari kemampuan kognitif. Anak usia 4-5 tahun menunjukkan peningkatan minat dalam angkaangka sederhana dan kuantitas kegiatan (seperti menghitung, mengukur, meneliti, kurang-lebih, besar-kecil).

\section{METODE PENELITIAN}

Menurut Sugiyono (2010:14), pendekatan kuantitatif adalah pendekatan yang digunakan untuk meneliti populasi atau sampel tertentu, pengumpulan data menggunakan instrumen penelitian, analisis data bersifat kuantitatif/statistik dengan tujuan untuk menguji hipotesis yang telah ditetapkan.

Tujuan penelitian eksperimen ini adalah untuk mengungkapkan hubungan variabel, atau mencari pengaruh suatu variabel terhadap variabel lainnya. Adapun sifatnya adalah melakukan perlakuan dan melakukan pengamatan atau pengukuran. Dengan cara ini peneliti sengaja membangkitkan timbulnya suatu kejadian yang kemudian diteliti bagaimana akibatnya.

Desain penelitian eksperimen yang digunakan dalam penelitian ini yaitu pre experimental design dengan rancangan one group pretest-posttest design. Penelitian ini mengunakan rancangan one group pretest-posttest design.

Populasi dari penelitian ini adalah anak kelompok A TK Tunas Harapan 1 Tunggunjagir Kabupaten Lamongan tahun ajaran 2017/2018 yang berjumlah 18 anak, terdiri dari 8 anak laki-laki dan 10 anak perempuan. Teknik penentuan sampel yang digunakan adalah Sampling Jenuh yang teknik pelaksanaannya dilakukan bila semua anggota populasi digunakan sebagai sampel. Hal ini dilakukan karena populasi relatif kecil yakni kurang dari 30 peserta didik (Sugiyono, 2011:85).

Penelitian ini untuk mengetahui kemampuan mengenal bilangan dan lambang bilangan anak yaitu menggunakan lembar instrumen observasi, pengambilan dokumentasi berupa foto atau vidio kegiatan anak selama bermain.

\section{HASIL PENELITIAN}

Pengumpulan data dan penyajian yaitu PreTest dan Post-Test dipaparkan dalam bentuk tabel yang selanjutnya dilakukan uji hipotesis, kemudian mencari hasil uji beda antara Pre-Test dan Post-Test dan mencari hasil uji signifikansi t-test $\left(\mathrm{t}_{\text {hitung }}\right)$ yang di lakukan anak kelompok A TK Tunas Harapan 1 Kabupaten Lamongan dengan jumlah 18 anak. Adapun hasil penelitian di sajikan dalam bentuk tabel sebagai berikut.

Tabel 1. Uji Beda Pre tes-Pos test 


\begin{tabular}{|c|c|c|c|}
\hline Subyek & Pre-Test & Post-Test & Gain \\
\hline 1 & 2,50 & 3,17 & 0,67 \\
\hline 2 & 2,63 & 3,25 & 0,63 \\
\hline 3 & 2,88 & 3,79 & 0,92 \\
\hline 4 & 2,38 & 3,08 & 0,71 \\
\hline 5 & 1,96 & 2,71 & 0,75 \\
\hline 6 & 2,42 & 3,13 & 0,71 \\
\hline 7 & 2,00 & 2,83 & 0,83 \\
\hline 8 & 2,92 & 3,88 & 0,96 \\
\hline 9 & 2,29 & 2,96 & 0,67 \\
\hline 10 & 2,88 & 3,75 & 0,88 \\
\hline $\begin{array}{l}11 \\
12\end{array}$ & $\begin{array}{l}2,92 \\
2,17\end{array}$ & $\begin{array}{l}3,83 \\
2,92\end{array}$ & $\begin{array}{l}0,92 \\
0,75\end{array}$ \\
\hline 13 & 2,67 & 3,58 & 0,92 \\
\hline 14 & 2,04 & 2,54 & 0,50 \\
\hline 15 & 2,08 & 2,67 & 0,58 \\
\hline 16 & 2,71 & 3,17 & 0,46 \\
\hline 17 & 2,46 & 3,13 & 0,67 \\
\hline 18 & 1,63 & 2,29 & 0,67 \\
\hline $\mathrm{N}=18$ & $\begin{array}{l}43,5 \\
\bar{x}_{1}=2,42\end{array}$ & $\begin{array}{c}56,67 \\
\bar{x}_{2}=1,30\end{array}$ & $\sum \mathrm{d}=13,17$ \\
\hline
\end{tabular}

Persiapan tabel uji hipotesis dapat dilihat pada tabel 2 dibawah ini.

\begin{tabular}{cccc}
\multicolumn{4}{l}{ Tabel 2. Persiapan uji hipotesis } \\
\hline Subyek & $\mathbf{d}$ & $\mathbf{x}_{\mathbf{d}(\mathbf{d}-\mathbf{M d} \mathbf{)}}$ & $\mathbf{x}_{\mathbf{d}}^{\mathbf{d}}$ \\
1 & 0,67 & $-0,06481$ & 0,00 \\
2 & 0,63 & $-0,10648$ & 0,01 \\
3 & 0,92 & 0,185185 & 0,03 \\
4 & 0,71 & $-0,02315$ & 0,00 \\
5 & 0,75 & 0,018519 & 0,00 \\
6 & 0,71 & $-0,02315$ & 0,00 \\
7 & 0,83 & 0,101852 & 0,01 \\
8 & 0,96 & 0,226852 & 0,05 \\
9 & 0,67 & $-0,06481$ & 0,00 \\
10 & 0,88 & 0,143519 & 0,02 \\
11 & 0,92 & 0,185185 & 0,03 \\
12 & 0,75 & 0,018519 & 0,00 \\
13 & 0,92 & 0,185185 & 0,03 \\
14 & 0,50 & $-0,23148$ & 0,05 \\
15 & 0,58 & $-0,14815$ & 0,02 \\
16 & 0,46 & $-0,27315$ & 0,07 \\
17 & 0,67 & $-0,06481$ & 0,00 \\
18 & 0,67 & $-0,06481$ & 0,00 \\
18 & $\sum \mathrm{d}=13,17$ & 0 & 0,37 \\
\hline
\end{tabular}

Menganalisis hasil penelitian kuantitatif eksperimen yang menggunakan desain PreExperimental Design dengan bentuk One-Group Pretest-Postest Design, sehingga dapat diperoleh $t_{\text {hitung }} 21,17$.

Uji hipotesis dengan cara dibawah ini:

$$
\begin{array}{rlrl}
\text { Jumlah responden }(\mathrm{N}) & =18 \\
\mathrm{db} & =\mathrm{N}-1=17 \\
t_{\text {hitung }} & & =21,17 \\
t_{\text {tabel }} & & =1,74 \\
& =2,57 \\
\text { Taraf signifikansi } & =5 \% t_{\text {tabel }} 1,74 \\
& & =1 \% t_{\text {tabel }} 2,57
\end{array}
$$

Hasil uji hipotesis di atas dapat disimpulkan bahwa bermain peran jual beli dapat berpengaruh terhadap kemampuan mengenal bilangan dan lambangan untuk anak kelompok A. Pengaruh tersebut sangat signifikan baik pada taraf kepercayaan $95 \%$ maupun $99 \%$.

\section{PEMBAHASAN}

Berdasarkan hasil penelitian diketahui bahwa ada pengaruh "bermain peran jual-beli terahadap kemampuan mengenal bilangan dan lambang bilangan pada anak kelompok A TK Tunas Harapan 1 Kabupaten Lamongan”. Perlakuan yang diberikan delapan kali menunjukkan anak mengalami perubahan pada perkembangan dalam kemampuan mengenal bilangan dan lambang bilangan. Treatment pertama anak masih terlihat bingung ketika diberikan metode bermain peran jual beli hanya ada 3 anak saja yang mengetahui permainan tersebut. Karena baru pertama kali dilakukan pada anak kelompok A TK Tunas Harapan 1 Kabupaten Lamongan.

Treatment ke dua anak-anak sudah mulai memahami permainan bermain peran jual-beli terlihat 5 anak yang mengalami perubahan dalam mengenal bilangan dan lambang bilangan dan 
mereka sangat menyukai permainan tersebut. Treatment selalu dilakukan setiap minggu dua kali dan pada treatment terakhir atau treatment ke delapan perubahan anak dalam mengenal kemampuan bilangan dan lambang bilangan hampir semuanya sudah terlihat ada peningkatan dari keseuruhan anak kelompok A yang berjumlah 18 anak.Peningkatan kemampuan yang terjadi pada anak dalam penelitian ini dikarenakan adanya (1) Ketertarikan anak dengan metode pembelajaran yang diberikan apalagi metode bermain peran belum pernah dilakukan sebelumnya,

Ketertarikan anak dengan media yang disediakan, hal ini ditunjukkan dengan antusiasnya anak saat dibagikan media untuk bermain peran, (3) Pemberian materi yang berbeda cara penyampaiannya dengan yang biasanya dilakukan dikelas secara klasikal menjadi pembelajaran yang menyenangkan karena dilakukan secara kreatif.

Perbandingan $t_{\text {hitung }} 21,27$ dan $t_{\text {tabel }} 1,74$ pada taraf kepercayaan 95\% membuktikan bahwa ada pengaruh bermain peran jual-beli terahadap kemampuan mengenal bilangan dan lambang bilangan pada anak kelompok A TK Tunas Harapan 1 Kabupaten Lamongan.

Hasil ini sesuai dengan juga dengan hasil penelitian Winda Wirasti Aguswara dan Julio menemukan kemampuan mengenal bilangan dan lambang bilangan perbedaan rata-rata kemampuan anak sebelum dan sesudah perlakuan, untuk kelompok eksperimen semula berjumlah 8,16 (pretest) kemudian meningkat menjadi 11,11 (pos-test). Selisih 2,95 poin antara rata-rata pre-test dan posttest menunjukkan secara kuantitatif bahwa kemampuan mengenal bilangan dan lambang bilangan mengalami peningkatan setelah diberikan perlakuan berupa uji statistik.

Pada pembelajaran berhitung, pengenalan pada aritmetika yang diterapkan Montessori (2013:363), beragam cara dapat digunakan untuk mengajarkan berhitung. Salah satu permainan yang bisa digunakan adalah menghitung dengan uang. Menggunakan uang tiruan anak-anak melakukan permainan bertukar uang dan menyajikan satu, dua, dan empat keping uang dan anak-anak akan berhitung sampai sepuluh.

Kurikulum yang diterapkan di OntarioCanada menurut (Ministry of Education. 2006), (The Full-Day Early Learning Kindergarten Program). Program pembelajaran awal pendidikan anak usia dini di Ontario-Canada berisi tentang cara yang digunakan anak-anak dalam pembelajarannya. Anak-anak menggunakan berbagai cara untuk memahami konsep angka 1-10 seperti, menggunakan ratusan diagram untuk membaca beberapa angka, menggunakan magnet dan kertas pasir angka untuk menuliskan angka atau menjumlahkan beberapa objek, menggunakan gambar nomer rumah di setiap rumah pada perumahan untuk mengenalkan angka, mencari dan mengenali angka dilingkungan rumahnya, menulis angka dan mengimajinasikan bill di restaurant untuk pusat bermain peran.

\section{SIMPULAN DAN SARAN}

\subsection{Simpulan}

Berdasarkan analisis data yang sudah dilakukan, maka dapat disimpulkan bahwa "bermain peran jual-beli berpengaruh terhadap kemampuan mengenal bilangan dan lambang 
bilangan anak kelompok A di TK Tunas Harapan 1 Kabupaten Lamongan.

\subsection{Saran}

Guru diharapkan untuk selalu aktif mencari inovasi dalam kegiatan pembelajaran. Adanya pengaruh bermain peran jual-beli terhadap kemampuan mengenal bilangan dan lambang bilangan anak menjadi contoh kegiatan pembelajaran yang dapat diterapkan. Pihak sekolah diharapkan banyak menyediakan sarana pembelajaran seperti adanya miniatur buah-buahan, sayur, atau benda nyata yang ada disekeliling anak, sehingga dapat menunjang kegiatan belajar anak yang berkaitan dengan perkembangan bermain peran jual-beli untuk mengenal bilangan dan lambang bilangan pada anak.

\section{PERNYATAAN TERIMA KASIH}

Peneliti mengucapkan banyak terima kasih setinggi-tingginya atas bantuan dari semua pihak dan para sahabat, yang tidak bisa disebutkan satu persatu sehingga penelitian ini selesai dengan tepat waktu. Peneliti memberi penghargaan besar atas kesabaran dan ketelatenan dosen pembimbing sampai peneliti tumbuh percaya diri untuk berani menghadapi tantangan dalam perjalanan menyelesaikan penelitian ini.

\section{REFERENSI}

Bergen, Doris. (2002). The Role of Pretend Play in Children's Cognitive Development. Early Childhood Researc and Practice (Online),Vol.4, No.1, The Role of Pretend Play in Children's Cognitive Development.html, http://ecrp.uiuc/V4n1/Bergen.htm, diunduh 15 Juli 2017 pukul 12.30 .
Julianto. (2013). Pengaruh Bermain Peran Jual Beli Terhadap Kemampuan Mengenal Bilangandan Lambang Bilangan. Skripsi, Universitas Negeri Surabaya.

Lee, Scott dan Goh, Gary. (2012). Action Research To Address the Transition from Kindergarten to Primary School: Children's Authentic Learning, Construction Play, and Pretend Play (Online), Vol.14,No.1, (http://ecrp.uiuc.edu/abtecrp.html), diunduh 14 Juli 2017 pukul 10.55.

Montessori, Maria dan Gerard Lee Gutek. (2013). Metode Montessori. Yogyakarta: Pustaka Pelajar

Sugiyono. (2010). Metedologi Penelitian Kuantitatif, Kualitatif dan R\&D. Bandung: Alfabeta.

Sujiono, Yuliani Nurani. (2009). Konsep Dasar Pendidikan Anak Usia Dini. .Jakarta: Indeks 
Incrementapedia: Jurnal Pendidikan Anak Usia Dini, 2019, 01 (02) $\mid 26$ 
